\title{
Treatment of X-disease of Peaches Using Oxytetracycline Microinjection Capsules
}

\author{
Daniel R. Cooley, Terry A. Tattar, and Julianne T. Schieffer \\ Department of Plant Pathology, University of Massachusetts, Amherst, \\ MA 01003
}

Additional index words. Prunus persica, tree injection, mycoplasma, rating system

\begin{abstract}
Oxytetracycline microinjection was assessed in four Massachusetts peach [Prunus persica (L.) Batsch] orchards where many trees were infected with X-disease. The injections significantly alleviated symptoms in all but the most severely diseased trees in the first year following treatment. This improvement was observed, to a lesser degree, the second season after treatment. Injection wounds did not callus and some damage to wood was observed around them, but after 2 years, there was no indication that injection wounds resulted in significant tree damage. Microinjection capsules offer an effective and more efficient injection treatment than existing methods.
\end{abstract}

Peach X-disease, caused by a mycoplasma-like organism (MLO) (Jones et al., 1974), can severely damage peaches. The only technique for eliminating or reducing $\mathrm{X}$-disease symptoms in infected trees is to inject them with the antibiotic oxytetracycline (OTC) (Douglas and McClure, 1988; Parker et al., 1963; Rosenberger and Jones, 1977). OTC therapy for peach $\mathrm{X}$-disease is an accepted and effective management tool, but it is somewhat cumbersome for peach growers to use. A sealed, pressurizable capsule containing OTC is available and might make X-disease treatment significantly easier. The capsules have the advantages over other techniques in requiring no chemical preparation and minimal time for making the injections. Many OTC injection methods for fruit trees have been compared, the key variables being OTC concentration and dose, injection equipment, and application timing (Allen and Davidson, 1978; Lacy, 1982; McCoy, 1982; McIntyre et al., 1979; Pearson and Sands, 1978; Rosenberger and Jones, 1977). Given an adequate dose, most injection techniques are successful, but they vary in terms of simplicity, cost, and phytotoxicity. In general, concentrated OTC $(\approx 75$ $\mathrm{mg} \cdot \mathrm{ml}^{-1}$ or higher $)$ is convenient, but relatively dilute OTC $\left(\approx 0.75 \mathrm{mg} \cdot \mathrm{ml}^{-1}\right.$ or less $)$ is less phytotoxic (Rosenberger and Jones, 1977; Sands and Walton, 1975). Doses in the range of 750 to $1250 \mathrm{mg}$ OTC/tree are sufficient to cause symptom remission (Pearson and Sands, 1978; Rosenberger and Jones, 1977; Sands and Walton, 1975). However, particularly from a peach-grower's perspective, it is not easy to apply that amount of OTC using presently recommended systems. While using prepared microinjection capsules would be easier, it is not clear that the

Received for publication 28 Mar. 1991. Accepted for publication 28 Aug. 1991. The cost of publishing this paper was defrayed in part by the pay ment of page charges. Under postal regulations, this paper therefore must be hereby marked $a d$ vertisement solely to indicate this fact. specific microinjection technique and the oxytetracycline formulation used will be effective in X-disease therapy, and because the OTC concentration is $40 \mathrm{mg} \cdot \mathrm{ml}^{-1}$, it is possible that phytotoxic side effects might result.

This experiment was undertaken to test the usefulness of the prepared microinjection capsules in treating X-disease. Additionally, we developed a simple and rapid rating system for X-disease symptoms that growers and consultants could use to make sound treatment decisions.

Trees in four commercial peach orchards in Massachusetts were selected for treatment in Sept. 1986. Each orchard included several cultivars. Tree age varied from 7 to 20 years. A significant number of trees at each site showed peach X-disease symptoms, as described previously (Douglas, 1986; Palmiter and Hildebrand, 1943; Stoddard, 1947). Foliage that was chlorotic, red-spotted, shotholed, tattered, brittle, or curled upward, or twigs with tufted foliage at the end and drop of older leaves were considered typical Xdisease symptoms. A rating system was developed for $\mathrm{X}$-disease severity: $0=$ apparently healthy, no X-disease symptoms; 1 = foliar X-disease symptoms on $10 \%$ or less of the crown; 2 = foliar X-disease symptoms and defoliation on more than $10 \%$ but less than $50 \%$ of the crown; $3=$ foliar $X$ disease symptoms and defoliation on between $50 \%$ and $90 \%$ of the crown; $4=$ more than $90 \%$ of the crown showing X-disease symptoms, including defoliation.

Polypropylene capsules, $\approx 4 \mathrm{~cm}$ in diameter $\times 10 \mathrm{~cm}$ long, containing $6 \mathrm{ml}$ of a $4 \%$ OTC solution, were used (J.J. Mauget Co., Los Angeles). The OTC solution had a final $\mathrm{pH}$ of 1.0 to 1.6 and a glycerol carrier. Capsule construction was such that pressure $(\approx 69$ to $83 \mathrm{kPa}$ ) could be generated in each capsule by compressing it slightly, either by hand or with a mallet. The pressurized capsule was then attached to a tapered plastic tube. The end of the tube was formed to insert into a 4.7-mm-diameter hole in the tree and bev- 
Table 1. Changes in peach $\mathrm{X}$-disease symptom ratings following injection with premixed encapsulated oxytetracycline.

\begin{tabular}{|c|c|c|c|c|c|c|c|}
\hline \multirow{4}{*}{$\begin{array}{l}\text { Pretreatment } \\
\text { rating }\end{array}$} & \multirow[b]{4}{*}{ Change } & \multicolumn{6}{|c|}{ Years post-treatment } \\
\hline & & \multicolumn{3}{|c|}{ One } & \multicolumn{3}{|c|}{ Two } \\
\hline & & \multicolumn{6}{|c|}{ Type of tree $(\%)^{y}$} \\
\hline & & Control & Treated & Significance & Control & Treated & Significance \\
\hline 0 & $\begin{array}{l}- \\
0 \\
+\end{array}$ & $\begin{array}{r}47 \\
53 \\
0\end{array}$ & $\begin{array}{r}9 \\
91 \\
0\end{array}$ & $*$ & $\begin{array}{r}20 \\
80 \\
0\end{array}$ & $\begin{array}{r}0 \\
100 \\
0\end{array}$ & NS \\
\hline 1 & $\begin{array}{l}- \\
0 \\
+\end{array}$ & $\begin{array}{l}75 \\
12 \\
13\end{array}$ & $\begin{array}{r}5 \\
19 \\
76\end{array}$ & $* * *$ & $\begin{array}{r}64 \\
27 \\
9\end{array}$ & $\begin{array}{l}22 \\
11 \\
67\end{array}$ & $* *$ \\
\hline 2 & $\begin{array}{l}- \\
0 \\
+\end{array}$ & $\begin{array}{r}21 \\
75 \\
4\end{array}$ & $\begin{array}{r}0 \\
20 \\
80\end{array}$ & $* * *$ & $\begin{array}{l}43 \\
43 \\
14\end{array}$ & $\begin{array}{r}6 \\
35 \\
59\end{array}$ & * \\
\hline 3 & $\begin{array}{l}- \\
0 \\
+\end{array}$ & $\begin{array}{l}10 \\
70 \\
20\end{array}$ & $\begin{array}{r}14 \\
7 \\
79\end{array}$ & $*$ & $\begin{array}{l}14 \\
72 \\
14\end{array}$ & $\begin{array}{l}50 \\
17 \\
33\end{array}$ & NS \\
\hline 4 & $\begin{array}{l}- \\
0 \\
+\end{array}$ & $\begin{array}{r}0 \\
100 \\
0\end{array}$ & $\begin{array}{r}0 \\
67 \\
33\end{array}$ & NS & $\begin{array}{r}0 \\
100 \\
0\end{array}$ & $\begin{array}{r}0 \\
67 \\
33\end{array}$ & NS \\
\hline
\end{tabular}

${ }^{2}$ Ratings scale: $0=$ no symptoms; $1=$ symptoms on $\leq 10 \%$ of crown; $2=$ symptoms on $>10 \%$ and $\leq 50 \%$ of crown; $3=$ symptoms on $>50 \%$ and $\leq 90 \%$ of crown; $4=$ symptoms on $>90 \%$ of crown. ${ }^{y}$ Calculated as percentage of the trees within each year, pretreatment rating, and treatment group that exhibited a negative $(-)$ or positive $(+)$ change or no change $(0)$.

$\mathrm{NS}, *, * *, * * *$ Nonsignificant or significant differences between rating changes of control and treated trees within each pretreatment rating each year at $P=0.05,0.01$, or 0.001 , respectively, as measured by the Mann-Whitney U test.

eled longitudinally to allow maximum contact with conductive tissue.

A battery-powered drill was used to drill one to three 4.7-mm-diameter holes into peach trunks 15 to $30 \mathrm{~cm}$ above ground level. One hole was used for each capsule. The number of capsules used depended on tree diameter, where one capsule was used per $5 \mathrm{~cm}$ of measured trunk diameter at the injection level. The injection holes were angled downward at $\approx 45^{\circ}$ and were $\approx 10$ to $12 \mathrm{~mm}$ deep. Capsule tubes were inserted immediately after the holes were drilled and tapped with a mallet to make a tight fit at the insertion point. This tap also broke a seal where the tube was inserted into the capsule and allowed OTC solution to flow into the hole. Generally, the content of each capsule was taken up within a few minutes, and all capsules emptied completely within $48 \mathrm{~h}$ of injection. All injections were made between 23 Sept. and 5 Oct. 1986.

Trees were rated before treatment and divided into two groups, 79 treated and 71 control trees. In each orchard, the number of treatment and control trees were about equal and divided in a completely random design. Over all orchards, the ratings in the two groups (1.7 and 1.4 for trees to be treated and the control, respectively) were not significantly different according to the Mann-Whitney test applied to individual tree ratings $(P \leq 0.05)$. Nonparametric statistics were used when comparing ratings because the data did not conform to assumptions of normality necessary for parametric tests.

One year after injection, the trees were rated again. Two years after injection, a subsample of the trees was rated again. (The subsample was necessary because one grower replanted a section of one block, reducing the number of treated trees to 53 and the number of control trees to 49 . This did not significantly change the random nature of the design, nor the pretreatment selection scheme.)

After 1 or 2 years, the OTC treatment had significantly reduced the development of symptoms. The OTC-treated trees had ratings of 0.7 and 1.5 for 1 and 2 years after treatment, respectively. Controls had ratings of 2.1 and 2.2 after 1 and 2 years, respectively. Fruit yield was also estimated 1 year after injection, where $0=$ no fruit, $1=$ less than average, $2=$ average, and $3=$ higher than average, with average defined relative to healthy, nonexperimental trees in the block. OTC treatments significantly enhanced yield 1 year after treatment. The average yield rating was 2.0 and 1.6 for treated and control trees, respectively. Our results agree with previous ones (Allen and Davidson, 1978; Sands, 1978; Rosenberger and Jones, 1977). The increase in yield occurred even when 480 to $720 \mathrm{mg}$ of OTC/tree was used, which is less than the 750 to $1250 \mathrm{mg}$ used by others (Pearson and Sands, 1978; Rosenberger and Jones, 1977; Sands and Walton, 1975).

Since treatment resulted in increased yield and symptom remission, an attempt was made to determine the disease level at which treatment would be most worthwhile. Symptom ratings after 1 year were compared to pretreatment ratings for each tree. The number of trees for which ratings changed positively, negatively, or did not change in the first year following treatment was calculated, and percentages of treated and nontreated trees were compared (Table 1). Rating changes for some trees were negative (i.e., symptoms worsened) in both groups, but many more control trees than OTC-treated trees declined. Trees Lacy, 1982; McCoy, 1982; Pearson and with a pretreatment rating of 0 could not improve, but nearly $50 \%$ of the control trees in this group developed symptoms, while only 9\% of the OTC-treated trees developed symptoms. For trees with a pretreatment rating of $1,13 \%$ of the control trees and $76 \%$ of the treated trees improved. For pretreatment ratings of $2,4 \%$ of the controls and $80 \%$ of the treated trees improved. For pretreatment ratings of $3,20 \%$ of controls and $79 \%$ of the treated trees improved. For pretreatment ratings of 4 , none of the controls and $33 \%$ of the treated trees improved. OTC treatments reduced X-disease symptoms in more than half of the trees with a pretreatment rating of 3 or lower. This held true even after factoring out nontreatment-related positive rating changes (i.e., the percentage of samples in the control group with a positive rating change). To test significance, the trees were divided into groups according to pretreatment ratings. The treated and nontreated trees within each group were compared using the Mann-Whitney test. The treated trees were ranked significantly higher in all groups, except the group originally rated $4(P \leq 0.05)$. Hence, in the first year after treatment, OTC-treated trees had less severe $\mathrm{X}$-disease symptoms, unless the pretreatment rating indicated symptoms were at the most severe level. Many OTC-treated trees showed symptom remission. Of trees that were asymptomatic at the time of the pretreatment rating (i.e., pretreatment rating $=$ 0 ), more OTC-treated trees maintained a symptom-free state compared to controls.

The effects of OTC were less pronounced the 2 nd year following treatment, but were still significant (Table 1). Using the individual Mann-Whitney tests according to pretreatment rating, OTC-treated trees had significant symptom improvement in the groups where the pretreatment ratings were 1 or 2 , but not where they were 0,3 , or 4 $(P \leq 0.05)$. This is not surprising in view of the relatively low dose of OTC used. Longterm (i.e., 2-year) symptom remission can be obtained when trees showing $\mathrm{X}$-disease symptoms are treated before the symptoms become severe (rating > 2).

Closure of treatment wounds by callus formation was poor after 2 years. At least one hole in most trees $(98 \%)$ did not callus. However, after 2 years, the wounds were not deteriorating and did not appear to be significantly affecting tree health. The issue of wounding was not entirely resolved. Treatment holes that were not injected with OTC would have been needed to resolve the extent to which the concentrated OTC inhibited wound closure. However, the wounds in this study did not show signs of significant fungal infection or decay. Most importantly, general tree health stayed vigorous, especially when compared to the nontreated controls.

The prepared microinjection system is efficacious and an efficient alternative to other methods of applying OTC for X-disease management. In view of the trunk injury observed, injections should be limited to those trees showing early $\mathrm{X}$-disease symptoms. The 
study suggests that injections of trees in which $50 \%$ or less of the crown shows symptoms would be effective if done every 2 years rather than every year. However, long-term studies are necessary to evaluate the cumulative effect of injections.

\section{Literature Cited}

Allen, W.R. and T.R. Davidson. 1978. Dosage response and duration of symptom remission in $\mathrm{X}$-diseased peach trees treated with oxytetracycline-HCI in Ontario. Plant Dis. Rptr. 62:311313.

Douglas, S.M. 1986. Initial stages of X-disease in peach: Within-tree spread and effects on growth. Phytopathology 76:1084.

Douglas, S.M. and M.S. McClure. 1988. New integrated approach for controlling X-disease of stone fruits. Connecticut Agr. Expt. Sta. Bul. 854.

Jones, A.L., G.R. Hopper, and D.A. Rosenberger. 1974. Association of mycoplasma-like bodies with little peach and X-disease. Phytopathology 64:755-756.

Lacy, G.H. 1982. Peach X-disease: Treatment site damage and yield response following antibiotic infusion. Plant Dis. 66:1129-1133.

McCoy, R.E. 1982. Use of tetracycline antibiotics to control yellows disease. Plant Dis. 66:539542.

McIntyre, J.L., H. Schneider, G.H. Lacy, J.A. Dodds, and G.S. Walton. 1979. Pear decline in Connecticut and response of trees to oxytetracycline infusion. Phytopathology 69:955-958.

Palmiter, D.H. and E.M. Hildebrand. 1943. The yellow red virosis of peach: Its identification and control. New York Agr. Expt. Sta. Bul. (Geneva) 704
Parker, K.G., D.H. Palmiter, R.M. Gilmer, and K.D. Hickey. 1963. X-disease of peach and cherry trees-and its control. New York Agr. Expt. Sta. Bul. 1100.

Pearson, R.C. and D.C. Sands. 1978. Eastern Xdisease of peach: Symptom remission and yield response following yearly injections of tetracyclines. Plant Dis. Rptr. 62:753-757.

Rosenberger, D.A. and AL. Jones. 1977. Symptom remission in X-diseased peach trees as affected by date, method, and rate of application of oxytetracycline-HCl. Phytopathology 67:277282.

Sands, D.C. and G.S. Walton. 1975. Tetracycline injections for control of Eastern X-disease and bacterial spot of peach. Plant Dis. Rptr. 59:573576.

Stoddard, E.M. 1947. The X disease of peach and its chemotherapy. Connecticut Agr. Expt. Sta. Bul. 506. 